\title{
Impact Analysis of Front Line Demonstrations on Yield and Economics of Mustard Crop in Banda District of Bundelkhand, Uttar Pradesh, India
}

\author{
B. K. Gupta*, Vivek Singh, B. K. Singh, Narendra Singh and B. P. Mishra \\ Agricultural Extension, Banda University of Agriculture and Technology, Banda, U.P., India \\ *Corresponding author
}

\author{
A B S T R A C T
}

\begin{tabular}{|l|}
\hline Ke y w o r d s \\
$\begin{array}{l}\text { Front line } \\
\text { demonstration, } \\
\text { Yield gap, } \\
\text { Economics, } \\
\text { Mustard }\end{array}$ \\
\hline Article Info \\
\hline $\begin{array}{l}\text { Accepted: } \\
12 \text { August } 2020 \\
\text { Available Online: } \\
\text { 10 September } 2020\end{array}$ \\
\hline
\end{tabular}

Rapeseed is grown in irrigated and non-irrigated condition as a rain fed crop. Production of rapeseed is also limited owing to non adoption of recommended agronomic which reduce the yield to a greater extent. The present study was carried out in 23 villages of Banda district of Bundelkhand, Uttar Pradesh, to know the impact and yield gaps between improved package of practices (IP) under Front Line Demonstration (FLD) and existing farmer's practice (FP) of mustard crops. Yield attributes of both demonstration and farmers' practice were recorded and their yield gap, technology gap, extension gap and technology index were analysed. The study shows that the yield of rapeseed -mustard in IP ranged from $11.75 \mathrm{qha}^{-1}$ to $13.75 \mathrm{qha}^{-1}$ whereas in FP it ranged between $08.55 \mathrm{qha}^{-1}$ to $10.45 \mathrm{qha}^{-1}$. The per cent increase in yield with IP over FP was recorded in the range of 29.19 to 44.23 percent. The technological gap and extension gap were ranging between $1.50-3.25 \mathrm{qha}^{-1}$ and 3.05-3.68 $\mathrm{qha}^{-1}$, respectively and the technological index 10.00 to 21.67 percent was recorded. The benefits cost ratio was 1.8- 3.5 under demonstration, while it was 1.4 to 2.2 under farmers practice. The result convincingly brought out that the yield of oil seed can be increase with the intervention on recommended package of practices. This also improved linkages between farmers and scientists, and built confidence for adoption of the improved technology.

\section{Introduction}

Rapeseed - mustard crops in India are grown in diverse agro climatic conditions ranging from north-eastern /north -western hills to down south under irrigated/rain fed timely/late sown, saline and mixed cropping. Indian mustard account for about $75-80 \%$ of the $6.07 \mathrm{~m}$ ha under this crops in the country during 2016-2017 crop season. India is the third largest rapeseed and mustard growing countries in the world after Canada and
China. Globally, India accounts for $19.8 \%$ of the total acreage and $09.8 \%$ per cent of the total production of the world (USDA 201617).

Rapeseed and mustard have caught the infatuation of farmers in Bundelkhand region is more particular area where the major crops are grown in rabi session only. Soybean, rapeseed-mustard and groundnut are the major oilseed crops in India contributing nearly $84 \%$ to $88 \%$ to its total acreage and 
production. Due to various factors the productivity of the crop is poor and it varies from year to year and place to place.

The mustard growing areas in India are experiencing the vast diversity in the agroclimatic conditions and different species of rapeseed-mustard are grown in some or other parts of the country (Shekhawat et al., 2012). Mustard/ rapeseed belong to the family Brassicaceae (Cruciferae). Two species of mustard and rapeseed are Brassica compestris and Brassica juncea. Oil content in the seed of toria is about 35 to $40 \%$. Its seed and oil is widely used in the preparation of different recipes like, vegetables, curries, pickles, medicines, hair oil and manufacture of greases. The oil cake is used as feed of cattle and manures for the plants. Oil cake is very useful for increase milk in milch cattle's. The leaves of young plants are used as green leafy vegetables and whole green plant is used as green fodder for animals.

In Bundelkhand region of Uttar Pradesh generally mustard are shown in month of September to mid of November and more are less in Banda district also. But most feasible and suitable time as per the farmers convenient during mid September to mid October when Kharif crops are harvested if any. In Bundelkhand mono cropping system is popular among the farming community due to the lack of assured irrigation facilities and other important factors farmers have to utilize the soil moisture as soon as possible, so preferably they shown the crop in month of last week of September to first week of October. Harvesting of kharif crop is done in the month of September to October. In Uttar Pradesh, Rai/mustard and toria is major oilseed crop of rabi season. It is grown in 0.68 million hectare area with total production of 0.95 million ton having productivity of 13.92 $\mathrm{qha}^{-1}$. In district Banda, total area is 7562 ha. with a production of 6517 MT having productivity of $8.62 \mathrm{qha}^{-1}$ (Directorate of Economics \& Statistics, DAC\&FW 2018). Banda district of Bundelkhand, U.P has a substantial area under mustard and rapeseed cultivation but the productivity level is quite low. The various reasons for low productivity like different production practices, insufficient knowledge of scientific cultivation, local verities, location specific production and protection technologies and their management practices at farmer's field. Keeping the above points in view, the FLD's on mustard and rapeseed using improved production technologies was conducted with the following objectives include to showing the production potential and production technologies of new mustard variety under actual farm situation; to compare the yield of FLDs plot and Farmers plot (check plot) and also to find out the technology gap, extension gap, technology index and economic impact of mustard.

\section{Materials and Methods}

A study was conducted in Banda district of Bundelkhand, U.P by the group of scientists of Banda University of Agriculture and Technology, Banda in the farmers field of 23 different villages of Banda district an area of 28.8 hectare was covered with plot size one acre under front line demonstration with active participation of farmers selected as respondents by following simple random sampling method. Total of 72 FLDs was conducted during Rabi season in three consecutive years (2016-17 - 2018-19). The ten best management practices (BMP) were selected comprised improved and locationspecific varieties (NRCHB 101), time of sowing, seed rate $(1.5 \mathrm{~kg} / \mathrm{acre})$, seed treatment, sowing method (line sowing), spacing, nutrient management, irrigation, timely weed management and plant protection measures (control of aphid through insecticide). During these three years of 
study, before conducting FLDs, a list of farmers of selected villages was prepared from group meeting and specific skill training was imparted to the selected farmers. The FLDs were conducted on farmers' field and monitored by experts.

The yield and economic performance data of demonstrations were collected for study the technology gap between the potential yield and demonstrated yield, extension gap between demonstrated yield and yield under existing practice and work out the technology index. The yield data were collected from both fields of demonstration and farmers practice by random crop cutting method and analyzed by using simple statistical tools. The observation on seed yield, straw yield per ha were recorded. To quantify the technology gap, extension gap and technology index the following formula was used:

Technology Gap $\left(\mathrm{qha}^{-1}\right)=$ Potential Yield Demonstration Yield

Extension Gap $\left(\mathrm{qha}^{-1}\right)=$ Demonstration Yield - Farmers Yield (Check Yield)

Technology Index $(\%)=$ Technology Gap/ Potential Yield X 100

\section{Results and Discussion}

The above study on mustard, the Table 1 indicates the detailed information about package of practices are used in demonstration of mustard crop as well as farmers practice. In the demonstration plot the cultivation practices includes improved and location-specific variety (NRCHB 101), time of sowing, seed rate $(1.5 \mathrm{~kg} /$ acre $)$, seed treatment, sowing method (line sowing), spacing, nutrient management, irrigation, timely weed management and plant protection measures.
It is revealed from Table 2 the total 72 Front Line Demonstrations was conducted during three consecutive years (2016-17 to 2018-19) in 28.8 ha area on farmer's fields of 23 different villages of Banda district of Bundelkhand region.

It is revelled from Table 3 yield of mustard in different demonstration plots was recorded and it ranged between $11.75 \mathrm{qha}^{-1}$ to 13.75 $\mathrm{qha}^{-1}$ and yield under farmers practice with local non descriptive verity recorded and it ranged between $08.55 \mathrm{qha}^{-1}$ to $10.45 \mathrm{qha}^{-1}$. during the study period. The demonstrated plot was recorded 29.19 to 44.23 per cent higher yield over farmer's variety. On an average 36.95 per cent increase in yield was recorded in the demonstration plots. Whereas, average farmers yield was recorded only $09.11 \mathrm{qha}^{-1}$.

The various factors are involved for the poor productivity in farmers practice like use of local non descript variety, early or late sowing may be due to owing to early or late vacation of field after harvesting of kharif crops and utilized the soil moisture for better germination of mustard as well as to avoid additional irrigation before sowing etc. During the month of September and October the temperature of this region are comparatively high $\left(36^{\circ} \mathrm{C}\right.$ to $\left.43^{\circ} \mathrm{C}\right)$ so they utilize soil moisture as soon as possible after harvesting of kharif crops. Besides these, farmers are not much serious about other important practices like application of recommended fertilizer doses before or after sowing, excess use of seed rate and low level of agronomic practices in addition to nonutilization of resources in time.

The results clearly depicts that positive effects of FLDs over the existing framers practices towards enhancing the yield of mustard crops in Banda district with its positive effects on yield. These results are in conformity with the 
findings of Mitra and Samajdar (2010) in FLD on rapeseed and mustard and of Rathod et al., (2013) in soybean produced on an average $38.83 \%$ more yield of rapeseed as compared to local practices.

The findings are in similarity with the findings of Singh (2002), Dhaka et.al. (2015), Lal et al., (2016) and Poonia \& Pithia (2011). The results are also in line with the findings of Katare et al., (2011), Meena et al., (2012) and Tomar et al., (2003).

\section{Technology gap}

It is revelled from Table 4 the technology gap in the demonstrated yield over potential yield was recorded $3.25,3.00$ and $1.50 \mathrm{q} \mathrm{ha}^{-1}$. in the year 2016, 2017 and 2018 respectively. It is also depicted from Table 4 that the average technology gap was $2.59 \mathrm{q} \mathrm{ha}^{-1}$ during the period of study. The technology gap ranging between 1.50-3.25 $\mathrm{qha}^{-1}$ reflected that the cooperation from farmer's side is appreciable in conducting FLDs with encouraging results in subsequent years. The variation in technology gap observed may be attributed to variation in soil fertility status and management practices. Similar finding was recorded by Mitra et al., (2010) and Katare et al., (2011).

Table1 Parameters and package of practices are used in demonstration of mustard crop as well as farmers practice

\begin{tabular}{|c|c|c|}
\hline Parameters & Demo. package & Farmers' practice \\
\hline Improved and location-specific varieties & NRCHB101 & Local/ non descriptive \\
\hline Time of sowing & $\begin{array}{l}\text { Last Week of October to } 1 \text { st } \\
\text { fortnight of November }\end{array}$ & $\begin{array}{l}\text { First week of October to } \\
\text { December }\end{array}$ \\
\hline Seed rate & $4 \mathrm{~kg} \mathrm{ha}^{-1}$ & $8-10 \mathrm{~kg} \mathrm{ha}^{-1}$ \\
\hline Seed treatment & Thiram @ 2gm/kg seed & No scheduled \\
\hline Sowing method & Line sowing & Broadcasting / Traditional \\
\hline Spacing (cm) & $30-45 \times 10$ & No specific \\
\hline $\begin{array}{l}\text { Nutrient Management (Ferti. dose in } \\
\text { Kg. NPKS) }\end{array}$ & 40:35:15: 10/ ha. & 20:20:0:0/ha. \\
\hline Irrigation & $\begin{array}{l}\text { One irrigation of } 6 \mathrm{~cm} \text { depth at } \\
50 \% \text { flowering stage }\end{array}$ & No scheduled irrigation \\
\hline Timely weed management & $\begin{array}{l}\text { Two hand weeding @ } 25 \text { and } \\
45 \text { days and thinning @ } 25 \text { days }\end{array}$ & No scheduled \\
\hline Plant Protection measures & $\begin{array}{l}\text { Against aphid (Lipaphis } \\
\text { erysimi) Foliar spray of } 625 \mathrm{ml} \\
\text { Dimethoate } 30 \mathrm{EC} \text { in } 200 \text { liter } \\
\text { water per ha. }\end{array}$ & Nil \\
\hline
\end{tabular}

Table.2 Year wise detail of front line demonstrations on mustard

\begin{tabular}{|c|l|l|l|c|c|}
\hline Year & Crop & Variety & Total Village & Area (ha) & No. of FLDs \\
\hline $\mathbf{2 0 1 6 - 2 0 1 7}$ & Mustard & NRCHB-101 & 08 & 9.6 & 24 \\
\hline $\mathbf{2 0 1 7 - 2 0 1 8}$ & Mustard & NRCHB-101 & 07 & 9.6 & 24 \\
\hline $\mathbf{2 0 1 8 - 2 0 1 9}$ & Mustard & NRCHB-101 & 08 & 9.6 & 24 \\
\hline \multicolumn{2}{|r}{ TOTAL } & & $\mathbf{2 3}$ & $\mathbf{2 8 . 8}$ & $\mathbf{7 2}$ \\
\hline
\end{tabular}


Table.3 Yield performance of mustard crop (Pooled data)

\begin{tabular}{|c|c|c|c|c|c|}
\hline \multirow[t]{2}{*}{ Year } & \multicolumn{3}{|c|}{ Yield $\left(q h^{-1}\right)$} & \multirow{2}{*}{$\begin{array}{l}\text { Additional } \\
\text { Yield over } \\
\text { local check } \\
\text { (q/ha) }\end{array}$} & \multirow{2}{*}{$\begin{array}{c}\text { Percent } \\
\text { Increase } \\
\text { Yield over } \\
\text { local check } \\
(\%)\end{array}$} \\
\hline & $\begin{array}{l}\text { Potential } \\
\text { Yield } \\
\text { (PY) }\end{array}$ & $\begin{array}{l}\text { Check Yield } \\
\text { (FP) }\end{array}$ & $\begin{array}{c}\text { Demo Yield } \\
\text { (IP) }\end{array}$ & & \\
\hline 2016 & 15.00 & 08.55 & 11.75 & 03.20 & 37.43 \\
\hline 2017 & 15.00 & 08.32 & 12.00 & 03.68 & 44.23 \\
\hline 2018 & 15.00 & 10.45 & 13.50 & 03.05 & 29.19 \\
\hline Mean & 15.00 & 09.11 & 12.42 & 03.31 & 36.95 \\
\hline
\end{tabular}

Table.4 Analysis of technology gap, extension gap and technology index in mustard crop under FLDs (pooled data)

\begin{tabular}{|l|c|c|c|}
\hline \multicolumn{1}{|c|}{ Year } & $\begin{array}{c}\text { Technology Gap } \\
(\mathbf{q} / \mathbf{h a})\end{array}$ & $\begin{array}{c}\text { Extension Gap (q/ha) } \\
\text { EG = IP or DP }- \text { FP }\end{array}$ & $\begin{array}{c}\text { Technology Index (\%) } \\
\text { TI = Tech. Gap/PY X 100 }\end{array}$ \\
\hline $\mathbf{2 0 1 6}$ & 03.25 & 03.20 & 21.67 \\
\hline $\mathbf{2 0 1 7}$ & 03.00 & 03.68 & 20.00 \\
\hline $\mathbf{2 0 1 8}$ & 01.50 & 03.05 & 10.00 \\
\hline MEAN & $\mathbf{0 2 . 5 9}$ & $\mathbf{0 3 . 3 1}$ & $\mathbf{1 7 . 2 3}$ \\
\hline
\end{tabular}

Table.5 Economic analysis of the demonstrated plot of mustard under FLDs (Pooled data)

\begin{tabular}{|c|c|c|c|c|c|c|c|c|}
\hline \multirow[t]{2}{*}{ Year } & \multicolumn{2}{|c|}{$\begin{array}{c}\text { Cost of } \\
\text { Cultivation } \\
\text { (Rs/ha) }\end{array}$} & \multicolumn{2}{|c|}{$\begin{array}{l}\text { Gross Return } \\
\quad \text { (Rs/ha) }\end{array}$} & \multicolumn{2}{|c|}{$\begin{array}{c}\text { Net Return } \\
\text { (Rs/ha) }\end{array}$} & \multicolumn{2}{|c|}{ B:C Ratio } \\
\hline & IP & FP & IP & FP & IP & FP & FP & IP \\
\hline 2016 & 18000 & 14500 & 39645 & 27089 & 21645 & 12589 & 1.86 & 2.2 \\
\hline 2017 & 20500 & 16000 & 43586 & 32790 & 23086 & 16790 & 2.04 & 2.12 \\
\hline 2018 & 22500 & 17000 & 46282 & 34764 & 23782 & 17764 & 2.04 & 2.05 \\
\hline MEAN & 20334 & 15834 & 43171 & 31544 & 22838 & 15715 & 1.99 & 2.12 \\
\hline
\end{tabular}

\section{Extension gap}

The extension gap showed an increasing trend in yield. The highest extension gap of $3.68 \mathrm{q}$ $\mathrm{ha}^{-1}$ was recorded during year 2017-18 followed by $3.20 \mathrm{q} \mathrm{ha}^{-1}$ during the year 201617 and the gap was least $3.05 \mathrm{q} \mathrm{ha}^{-1}$. During 2018-19 years of study. The table also shows that the average extension gap was recorded $3.31 \mathrm{q} \mathrm{ha}^{-1}$. It is because of the farmers generally not aware about HYV and lost yield potential of the non-descriptive varieties due to continuous use year after years. Package of practices which is recommended by scientist with best course of action. To minimise the extension gap it need to be find out the some basic cause, educate them and plan the appropriate extension strategies through various means for adoption of improved technologies. The light of hope exists in decreasing trend of the extension gap with the continuity of the study in specific area through demonstration and other appropriate extension methods. 


\section{Technology index}

The technology index shows the feasibility of the evolved technology at the farmers' fields and the lower the value of technology index more feasibility of the technology. Table 4 shows the technology index and it ranged from 10.00 to 21.67 . During the study year 2016-17 the technological index 21.67 percent was recorded followed by 20.00 percent during the year to 2017-18 and the technological index was recorded during the year 2018-19 is 10.00 percent and the average value of technological index during the study year from 2016 to 2018 was 17.23 percent. The table clearly indicate that the values are in decreasing trends which proves the feasibility of the technology demonstrated in farmer's field. These results are line with the earlier findings of Mitra and Samajdar (2010) who indicate that lower the value of technology index, more is the feasibility of the technology demonstrated. Similar findings were also reported by Kirar et al., (2006), Meena et al., (2016), Singh et al., (2014).

\section{Economic analysis of the demonstrated plot}

It is revelled from Table 5 that the average cost of cultivation of mustard crop in demonstrated plot is Rs. 20334 /ha and the average cost of cultivation of farmers plot is Rs. 15834 /ha. The gross return of demonstrated plot was recorded Rs. 43171/ha as compare to farmers plot (check plot) Rs 31544/ha and Net return Rs 22838/ha was recorded high in demonstrated plot as compare to farmers plot (check plot) Rs 15715 /ha. The benefit cost ratio (B: C ratio) of demonstrated plot was 2.12 and of 1.99 of farmers plot (check plot). This may be due to higher yield obtained and lower cost of cultivation under improved technologies compared to farmers practice (local check). This finding is in corroboration with the findings of Mokidue et al., (2011), Verma et al., (2016) and Raj et al., (2013). Hence, higher $\mathrm{B}: \mathrm{C}$ ratios proved economic viability of the interventions made under FLD. Similar findings were also reported by Balai et al., (2012) in rapeseed and mustard and Sharma (2003) in moth bean.

In conclusion front line demonstration (FLDs) play a very important role to disseminate recommended technologies among the farming community and it shows the potential of technology resulting an increased in yield at farmer's level. The result convincingly brought out that the yield of oil seed can be increase with the intervention on recommended package of practices. This also improved linkages between farmers and scientists, and built confidence for adoption of the improved technology. Productivity enhancement under FLDs over farmer practices of pulses cultivation created a greater awareness, and motivated other farmers those who do not growing mustard crops they also adopt improved technologies. These practices may be popularized in this area through different means of transfer of technology by the extension agencies.

\section{Consent}

As per international standard farmers written consent has been collected and preserved by the author(s) for conducting demonstration.

\section{Competing interests}

Authors have declared that no competing interests exist.

\section{Authors' contributions}

The work is carried out by the contribution of all the Authors. Author BKG, designed and conducted the demonstrations at farmer's field. Author VS, BKS and NS supervised and provided necessary support to team for 
smooth execution of demonstrations. Author BKG and BPM wrote the first draft of manuscript and statistically analyzed.

\section{Acknowledgment}

The authors acknowledge the contribution of scientists of DRMR, Bharatpur, Rajasthan for their technical support to conducting FLDs. We also acknowledge to the farmers for unconditional support during the study.

\section{References}

Agricultural Statistics at Glance 2018 (Directorate of economics and statistics, DAC\& FW 2017-18).

Balai, C.M., Meena, R.P., Meena, B.L. and Bairwa, R.K. (2012). Impact of front line demonstration on rapessed and mustard yield improvement . Indian Res. J. Ext. Edu. 12 (2): 113-116

Dhaka, B.L., Poonia, M.K., Meena, B.S. and Bairwa, R.K. 2015. Yield and economic viability of coriander under front line demonstrations in Bundi district of Rajasthan. J. Hortl. Sci.., 10(2): 226-28

Katare, Subhash; Pandey S.K. and Mustafa, Mohd (2011). Yield gap analysis of Rapeseed-mustard through front line demonstrations. Agric. Update, 6: 5-7.

Kirar, B.S., Narshine, R., Gupta, A.K. and Mukherji, S.C. 2006. Demonstration: An effective tool for increasing the productivity of Urd. Ind.Res.J. of Ext. Edu., 6(3):47-48

Lal, G., Mehta, R.S., Meena, R.S., Meena, N.K. and Choudhry, M.L. 2016. Impact of front line demonstration (FLDS) on yield enhancement of coriander: A case study in TSP area of Pratapgarh. E News Letter ICAR- National Research Centre on Seed Spices, 8(3): 5-6.

Meena, BL; Meena RP; Meena RH and Balai CM (2012). Yield gap analysis of rapeseed-mustard through front line demonstrations in agroclimatic zone IV of Rajasthan. J. Oilseed Brassica, 3(1): 51-55

Meena, K.C., Singh, D.K., Gupta, I.N., Singh, B., Meena, S.S. 2016. Popularazation of coriander production technologies through front line demonstrations in Hadauti region of Rajasthan. Int. J. Seed Spices, 6(2): 24-29

Mitra, B., and Samajdar, T. (2010). Yield gap analysis of rapeseed- mustard through front line demonstration. Agri. Ext. Review, XXII (2): 16-17.

Mokidue I, Mohanty A.K., and Sanjay, K (2011) Correlating growth, yield and adoption of urd bean technologies. Indian J. Ex. Edu. 11(2): 20-24.

Poonia TC and Pithia MS 2011. Impact of front line demonstrations of chickpea in Gujarat. Legume Res. 34(4): 304-307.

Raj A. D., V. Yadav and J. H. Rathod 2013.Impact of Front Line Demonstration (FLD) on the yield of pulses. International Journal of Scientific and Research Publications, 3 (9): $1-4$

Rathod, M.K., Tidke, G.R. and Mandve, R.P. (2013). Impact of Front line Demonstration on adoption of Seed treatment in Soybean. Indian Res. J. Ext. Edu. 13 (2): 72-77

Sharma, O. P. (2003). Moth bean yield improvement through front line demonstration. Agri. Ext. Review, 15 (5): 11-13 Indian Mustard (Brassica juncea (L.) Czernj. Cosson): Intl. J. Agronomy, 2012: 14.

Shekhawat, K., Rathore, S.S., Premi, O.P., Kandpal, B. K. and Chauhan, J.S. (2012). Advances in Agronomic Management of Indian Mustard (Brassica juncea (L.) Czernj. Cosson): Intl. J. Agronomy, 2012: 14.

Singh Dhananjai, A.K. Patel, M.S. Baghel, Alka Singh, A. K. Singh 2014. Technological Intervention for 
Reducing the Yield Gap of Chick Pea (Cicer arietinum L.) in Sidhi District of M.P. International Journal of Advanced Research in Management and Social Sciences, 3(3):117-122

Singh, PK. 2002. Impact of participation in planning on adoption of new technology through FLD. MANAGE Extension Research Review, JulyDec. $45-48$

Tomer, L.S; Sharma, B.P. and Joshi, K. (2003). Impact of Front Line
Demonstration of soybean in transfer of improved technology. J. Ext. Edu., 22: 139.

USDA (2010). United State Department of Agriculture, Annual Report.

Verma, Arjun Kumar, Singh, Mahendra, Singh, Navab, Jeenger, K.L. and Verma, J.R. 2016. Dissemination of improved practices of coriander through FLDS in Zone V of Rajasthan province. Int. J.S Sci. Envion. Tech., 5(5): 332027.

\section{How to cite this article:}

Gupta, B. K., Vivek Singh, B. K. Singh, Narendra Singh and Mishra, B. P. 2020. Impact Analysis of Front Line Demonstrations on Yield and Economics of Mustard Crop in Banda District of Bundelkhand, Uttar Pradesh, India. Int.J.Curr.Microbiol.App.Sci. 9(09): 1251-1258. doi: https://doi.org/10.20546/ijcmas.2020.909.153 